\title{
Circulatory Imbalance of Essential and Toxic Trace Elements in Pre-dialysis and Hemodialysis Patients
}

\author{
Aleksandar Stojsavljević ${ }^{1,2}$ • Danijela Ristić-Medić ${ }^{3}$ • Đurđa Krstić ${ }^{1}$ Branislav Rovčanin ${ }^{4}$ - Slavica Radjen ${ }^{5,6}$. \\ Brankica Terzićc ${ }^{6,7}$. Dragan Manojlović ${ }^{1,8}$
}

Received: 11 August 2021 / Accepted: 23 September 2021 / Published online: 29 September 2021

(c) The Author(s), under exclusive licence to Springer Science+Business Media, LLC, part of Springer Nature 2021

\begin{abstract}
The status of essential and toxic trace elements in patients with different stages of chronic kidney disease (CKD) is still unclear and not well characterized. The present study examined the circulatory levels of a wide panel of trace elements (Al, $\mathrm{Cr}, \mathrm{Mn}, \mathrm{Co}, \mathrm{Ni}, \mathrm{Cu}, \mathrm{Zn}, \mathrm{As}, \mathrm{Se}, \mathrm{Rb}, \mathrm{Sr}, \mathrm{Cd}, \mathrm{Pb}$, and $\mathrm{U}$ ) in hemodialysis patients (HD group) and pre-dialysis patients with stage $3 \mathrm{CKD}$ (PD group). Comparisons were made between groups of patients and healthy individuals from the control group (CG). The levels of $\mathrm{Al}, \mathrm{Mn}, \mathrm{Co}, \mathrm{Ni}, \mathrm{Cu}, \mathrm{As}, \mathrm{Se}, \mathrm{Sr}$, and $\mathrm{Pb}$ were higher, while the levels of $\mathrm{Cr}, \mathrm{Zn}, \mathrm{Rb}, \mathrm{Cd}$, and $\mathrm{U}$ were lower in $\mathrm{HD}$ patients than in our CG. Higher levels of $\mathrm{Al}$ and $\mathrm{Se}$, as well as lower levels of $\mathrm{As}, \mathrm{Sr}, \mathrm{Zn}, \mathrm{Rb}$, and U were significant and distinguished HD from PD. Among other analyzed elements, $\mathrm{Co}, \mathrm{Se}$, and $\mathrm{U}$ are the only trace elements that did not distinguish PD from CG at a statistically significant level. The HD group had lower serum U levels than the PD group, and this could be a result of hemodialysis. This study also revealed that the $\mathrm{Cu} / \mathrm{Zn}$ ratio could be used as a marker for early and late detection of renal failure. Marked changes of essential and toxic trace element levels in sera indicate additional pathophysiological events in CKD, which could additionally contribute to the preexisting increased morbidity of HD patients. Measurement of trace elements in HD patients should be performed routinely.
\end{abstract}

Keywords Pre-dialysis patients $\cdot$ Hemodialysis patients $\cdot$ Essential trace elements $\cdot$ Toxic trace elements

Aleksandar Stojsavljević

aleksandars@chem.bg.ac.rs

1 Faculty of Chemistry, University of Belgrade, Studentski trg 12-16, Belgrade, Serbia

2 Innovation Center of the Faculty of Chemistry, University of Belgrade, Studentski trg 12-16, Belgrade, Serbia

3 Group for Nutritional Biochemistry and Dietology, Centre of Research Excellence in Nutrition and Metabolism, Institute for Medical Research, National Institute of Republic of Serbia, 11000 Belgrade, Serbia

4 Center for Endocrine Surgery, University Clinical Center of Serbia, Koste Todorovića 8, Belgrade, Serbia

5 Medical Faculty of the Military Medical Academy, University of Defence, Belgrade, Serbia

6 Institute of Hygiene, Military Medical Academy, Belgrade, Serbia

7 Clinic of Nephrology, Military Medical Academy, Belgrade, Serbia

8 South Ural State University, Lenin Prospect 76, Chelyabinsk, Russia

\section{Introduction}

The homeostasis of trace elements depends on both biliary excretion and optimal renal excretory function [1]. When normal excretory ability becomes inadequate as a result of chronic kidney disease (CKD), hemodialysis (HD) is one of the interventional treatment methods enabling the preservation of vital functions [2]. HD removes uremic toxins based on the concentration gradient between blood plasma and dialysate across a semi-permeable membrane. Depletion of essential substances can occur if the level of the substance in the dialysate is lower than in the blood. The same effect can occur if they are not included in the dialysate. Conversely, if the substance is present in the dialysate but not in the blood, then clinically significant toxicity can occur as a result of substance transfer across the membrane into the circulatory system [3]. Furthermore, the lack of renal clearance in HD patients can lead to an overload of toxic trace elements that originate via ingestion and/or inhalation, even when not present in the dialysate [4]. Therefore, HD patients are at risk for both deficiency and metal intoxication 
effects, depending on residual renal function, dietary intake, and quality of the HD procedure [5, 6]. According to the glomerular filtration rate (GFR) values, five stages of CKD are defined. Patients with end-stage renal disease (ESRD), which is denoted as stage $5 \mathrm{CKD}$, are particularly susceptible to these effects, since the GFR is lower than $15 \mathrm{~mL} /$ $\mathrm{min} / 1.73 \mathrm{~m}^{2}$. Stage 3 CKD is characterized by GFR values in the interval $30-59 \mathrm{~mL} / \mathrm{min} / 1.73 \mathrm{~m}^{2}$; at this stage, $\mathrm{HD}$ is initially considered as a therapeutic option [7].

The amounts of biologically important trace elements (such as $\mathrm{Mn}, \mathrm{Cu}, \mathrm{Zn}$, and $\mathrm{Se}$ ) in a patient's body can be abnormal as a result of poor dietary intake (anorexia nervosa, bulimia, and dietary restrictions) or due to the HD procedure itself [7]. Different trace elements have diverse binding affinities for plasma proteins, indicating their unequal loss during HD. For example, Sr and Mn were found to have $77 \%$ and $71 \%$ binding rates, respectively, while Se and $\mathrm{Zn}$ had 25 and $15 \%$ binding rates. Therefore, these two latter trace elements are more susceptible to losses during $\mathrm{HD}$ compared to $\mathrm{Sr}$ and $\mathrm{Mn}$. In contrast, xenobiotics such as toxic trace elements ( $\mathrm{As}, \mathrm{Cd}, \mathrm{Pb}, \mathrm{Sr}, \mathrm{U}, \mathrm{Rb}$, and others) tend to accumulate in the body as a result of excretory mechanism losses or due to contamination with large amounts of dialysis fluid (>120 L/week) [6]. Thus, environmental factors, exposure, and dialysis water quality should be monitored.

Changes in the levels of essential and toxic trace elements in serum samples of CKD patients are an important issue that remains to be resolved. Additionally, the loss of trace element homeostasis in ESRD patients significantly contributes to their increased morbidity and mortality. In this regard, this study aimed to examine the levels of a wide panel of trace elements (Al, Cr, Mn, Co, Cu, Zn, As, Se, $\mathrm{Rb}, \mathrm{Sr}, \mathrm{Cd}, \mathrm{Pb}$, and $\mathrm{U}$ ) in the serum samples of hemodialysis patients with ESRD (HD group) and in pre-dialysis patients (PD group). Comparisons were made between groups of patients as well as with healthy people with normal kidney function (control group - CG). This design of experimental groups enables the evaluation of gradation of trace element homeostasis starting from healthy individuals, followed by an intermediate stage of CKD and the terminal ESRD cases.

\section{Material and Methods}

\section{Sample Collection}

The study included 37 HD patients (female $/$ male $=10 / 27$; mean age $=56.7 \pm 13.1$ years), 34 patients with stage 3 $\mathrm{CKD}$ (female $/ \mathrm{male}=8 / 26$; mean age $=57.1 \pm 9.93$ years), and 50 healthy blood donors (female/male $=14 / 36$; mean age $=55.2 \pm 11.2$ years) in the CG. The definitive diagnosis of CKD was confirmed by fulfilling clinical, radiological, and/or histopathological criteria for diagnosis, according to the Clinical Practice Guidelines for Chronic Kidney Disease of National Kidney Foundation (2012 KDIGO clinical practice guideline for the evaluation and management of CKD) [7]. The average time patients had been on HD was $6 \pm 4$ years. Primary causes of CKD in PD patients are hypertension $(60 \%)$, diabetic nephropathy $(23.3 \%)$, glomerulonephritis (10\%), and polycystic kidney disease $(6.67 \%)$. Diagnoses that lead to end-stage CKD and hemodialysis procedures were hypertension $(52.38 \%)$, diabetic nephropathy (23.81\%), glomerulonephritis (14.29\%), and polycystic kidney disease $(9.52 \%)$. Patients were dialyzed three times per week for $4 \mathrm{~h}$ using a polysulfone dialysis membrane. The water used for HD was prepared according to international standard ISO 13959: 2014. In order to analyze the parameters, blood samples were taken before the second weekly dialyses. The CG consisted of untreated healthy volunteers recruited for routine general examination without renal failure or any other medical disorder that could significantly affect the homeostasis of trace elements. These individuals were matched by age with patients from both the HD and PD groups.

Blood samples from HD patients were taken in the middle of the week, after 12-14 h of overnight fasting and immediately prior to dialysis. Blood samples from patients with stage 3 CKD and healthy individuals were collected in the morning after overnight fasting. All blood samples were collected into trace element-free evacuated tubes (BD Vacutainer). At the time of blood sampling, 10\% of patients were receiving magnesium supplements, without taking any other minerals. The collected whole peripheral blood $(5 \mathrm{~mL})$ from each subject was left for approximately $30 \mathrm{~min}$ to coagulate, and the obtained serum was separated after centrifugation $(3000 \times g)$ into decontaminated, trace element free, Eppendorf tubes. All serum samples were frozen at $-80^{\circ} \mathrm{C}$ until analysis.

In order to avoid confounding factors that could influence the distribution of trace elements, patients who had other medical conditions, such as gastrointestinal, inflammatory, hepatic, respiratory, malignant, and autoimmune diseases, who excessively used alcohol or who had a history of substance abuse were excluded from this study. The patients were clinically stable, with adequate nutrition status, and with no recorded cardiovascular events. None of the patients was receiving corticosteroid, anti-inflammatory, or cytotoxic drugs. Moreover, patients who were employed in any chemical industry or in similar places that might interfere with the ingestion/inhalation of trace metals were also excluded. All study participants signed written informed consent to participate in this study, which was approved by the Ethical Review Board of the Military Medical Academy, Belgrade, Serbia, in accordance with the principles of the Declaration of Helsinki. 


\section{Laboratory Procedures}

Serum samples were prepared according to Stojsavljević et al. [8]. Briefly, serum samples were diluted 10 times with an aqueous solution containing $0.05 \%$ nitric acid, $0.1 \%$ Triton X-100, and 3\% n-butanol. All elements were quantified by inductively coupled plasma mass spectrometry (ICP-MS) (iCAP $\mathrm{Q}_{\mathrm{c}}$, Thermo Scientific, UK) in standard mode and by adding an internal standard solution, containing ${ }^{45} \mathrm{Sc}$ at a concentration of $50 \mu \mathrm{g} / \mathrm{L}$ and ${ }^{71} \mathrm{Ga}$, ${ }^{89} \mathrm{Y},{ }^{115} \mathrm{In},{ }^{159} \mathrm{~Tb}$, and ${ }^{208} \mathrm{Bi}$ at concentrations of $10 \mu \mathrm{g} / \mathrm{L}$, in equal amounts to each test solution. Linearity of the calibration curve above 0.99 was obtained for each element in the range from 1 to $50 \mu \mathrm{g} / \mathrm{L}$ ( $\mathrm{Al}, \mathrm{Cr}, \mathrm{Mn}, \mathrm{Co}, \mathrm{Ni}, \mathrm{As}, \mathrm{Sr}$, $\mathrm{Cd}, \mathrm{Pb}$, and $\mathrm{U}$ ) or from 1 to $250 \mu \mathrm{g} / \mathrm{L}(\mathrm{Cu}, \mathrm{Zn}, \mathrm{Se}$, and $\mathrm{Rb}$ ). Accuracy was assessed by analysis of certified reference material (CRM) Seronorm ${ }^{\text {TM }}$ Trace Elements Serum L-1. According to the results obtained with CRM, the following isotopes were selected: ${ }^{27} \mathrm{Al},{ }^{53} \mathrm{Cr},{ }^{55} \mathrm{Mn},{ }^{59} \mathrm{Co},{ }^{60} \mathrm{Ni}$, ${ }^{65} \mathrm{Cu},{ }^{67} \mathrm{Zn},{ }^{75} \mathrm{As},{ }^{78 / 82} \mathrm{Se},{ }^{85} \mathrm{Rb},{ }^{88} \mathrm{Sr},{ }^{111} \mathrm{Cd},{ }^{208} \mathrm{~Pb}$, and ${ }^{238} \mathrm{U}$ (obtained recovery values for selected isotopes ranged from 92.4 to $119.2 \%$ ).

\section{Data Analysis}

Statistical analysis was conducted using SPSS statistical software (IBM Statistics v.20). Data were summarized as the mean and standard deviation $(S D)$, median and range (min-max), as well as geometric mean (GM) and percentiles (Ps) from the 5 th to the 95 th. The normality of data was tested using the Shapiro-Wilk test. Comparisons between groups were performed using the Kruskal-Wallis one-way analysis of variance and Mann-Whitney $U$ test. $P$ value below 0.05 was considered statistically significant. Principal component analysis (PCA) was performed in the software package PLS ToolBox, v. 6.2.1, Matlab 7.12.0 (R2011a); all data were auto-scaled before the multivariate analysis.

\section{Results}

The parameters of descriptive statistics, together with the GMs and selected Ps for elements in the serum samples of CG, PD, and HD, are given in Tables 1, 2, and 3, respectively. Copper $(\mathrm{Cu})$ was the most abundant element in all three groups, followed by zinc ( $\mathrm{Zn})$, rubidium $(\mathrm{Rb})$,
Table 1 Parameters of descriptive statistics, together with geometric mean (GM) and selected percentiles (Ps) in serum samples for trace elements $(\mu \mathrm{g} / \mathrm{L})$ in the control group $(\mathrm{CG})$

\begin{tabular}{lcccccccccccccc}
\hline & $\mathrm{Al}$ & $\mathrm{Cr}$ & $\mathrm{Mn}$ & $\mathrm{Co}$ & $\mathrm{Ni}$ & $\mathrm{Cu}$ & $\mathrm{Zn}$ & $\mathrm{As}$ & $\mathrm{Se}$ & $\mathrm{Rb}$ & $\mathrm{Sr}$ & $\mathrm{Cd}$ & $\mathrm{Pb}$ & $\mathrm{U}$ \\
\hline Mean & 5.87 & 0.54 & 2.34 & 0.76 & 2.59 & 855 & 607 & 0.54 & 61.8 & 160 & 24.6 & 0.05 & 0.31 & 0.021 \\
SD & 3.83 & 0.47 & 1.95 & 0.24 & 1.00 & 219 & 125 & 0.32 & 14.4 & 31.5 & 8.33 & 0.03 & 0.24 & 0.025 \\
Min & 1.90 & 0.15 & 0.61 & 0.40 & 1.26 & 500 & 410 & 0.09 & 33.8 & 65.1 & 10.3 & 0.01 & 0.05 & 0.002 \\
Max & 19.4 & 1.83 & 7.94 & 1.59 & 5.44 & 1486 & 940 & 1.44 & 99.8 & 226 & 48.7 & 0.19 & 1.47 & 0.121 \\
Median & 4.56 & 0.32 & 1.62 & 0.69 & 2.31 & 826 & 583 & 0.46 & 63.0 & 157 & 22.7 & 0.04 & 0.23 & 0.009 \\
GM & 5.00 & 0.41 & 1.80 & 0.73 & 2.43 & 828 & 594 & 0.45 & 60.1 & 157 & 23.3 & 0.04 & 0.25 & 0.012 \\
P5 & 2.33 & 0.19 & 0.66 & 0.49 & 1.46 & 561 & 436 & 0.15 & 40.1 & 118 & 14.3 & 0.02 & 0.09 & 0.004 \\
P25 & 3.35 & 0.25 & 1.07 & 0.64 & 1.87 & 677 & 510 & 0.35 & 48.3 & 137 & 18.7 & 0.03 & 0.17 & 0.006 \\
P50 & 4.56 & 0.32 & 1.62 & 0.69 & 2.31 & 826 & 583 & 0.46 & 63.0 & 157 & 22.7 & 0.04 & 0.23 & 0.009 \\
P75 & 7.07 & 0.60 & 2.64 & 0.84 & 3.04 & 1015 & 687 & 0.70 & 70.9 & 178 & 27.6 & 0.06 & 0.38 & 0.023 \\
P95 & 12.9 & 1.67 & 7.33 & 1.22 & 4.89 & 1228 & 816 & 1.31 & 83.7 & 215 & 39.4 & 0.10 & 0.65 & 0.073 \\
\hline
\end{tabular}

Table 2 Parameters of descriptive statistics, together with geometric mean (GM) and selected percentiles (Ps) in serum samples for trace elements $(\mu \mathrm{g} / \mathrm{L})$ in the predialysis patients (PD group) with 3rd stage chronic kidney disease

\begin{tabular}{lcccccccccccccc}
\hline & $\mathrm{Al}$ & $\mathrm{Cr}$ & $\mathrm{Mn}$ & $\mathrm{Co}$ & $\mathrm{Ni}$ & $\mathrm{Cu}$ & $\mathrm{Zn}$ & $\mathrm{As}$ & $\mathrm{Se}$ & $\mathrm{Rb}$ & $\mathrm{Sr}$ & $\mathrm{Cd}$ & $\mathrm{Pb}$ & $\mathrm{U}$ \\
\hline Mean & 11.2 & 0.15 & 4.06 & 0.96 & 8.86 & 1148 & 445 & 0.97 & 68.7 & 190 & 51.8 & 0.014 & 3.04 & 0.013 \\
SD & 2.33 & 0.12 & 1.02 & 0.47 & 1.30 & 186 & 82.2 & 0.15 & 24.6 & 39.8 & 14.4 & 0.003 & 1.36 & 0.009 \\
Min & 5.28 & 0.02 & 2.55 & 0.60 & 5.52 & 882 & 249 & 0.51 & 44.0 & 133 & 31.3 & 0.006 & 0.99 & 0.001 \\
Max & 15.0 & 0.51 & 7.04 & 2.44 & 11.3 & 1499 & 635 & 1.20 & 157 & 280 & 90.6 & 0.019 & 7.20 & 0.039 \\
Median & 11.6 & 0.13 & 4.01 & 0.76 & 9.04 & 1146 & 443 & 1.01 & 62.0 & 184 & 47.0 & 0.014 & 2.94 & 0.014 \\
GM & 11.0 & 0.12 & 3.95 & 0.88 & 8.76 & 1134 & 437 & 0.95 & 65.6 & 187 & 50.0 & 0.014 & 2.78 & 0.009 \\
P5 & 7.17 & 0.03 & 2.67 & 0.62 & 6.71 & 906 & 318 & 0.64 & 45.2 & 141 & 35.0 & 0.009 & 1.31 & 0.001 \\
P25 & 9.93 & 0.08 & 3.39 & 0.71 & 8.08 & 984 & 393 & 0.98 & 55.1 & 160 & 42.8 & 0.013 & 2.13 & 0.008 \\
P50 & 11.6 & 0.13 & 4.01 & 0.76 & 9.04 & 1146 & 443 & 1.01 & 62.0 & 184 & 47.0 & 0.014 & 2.94 & 0.014 \\
P75 & 12.6 & 0.18 & 4.39 & 0.90 & 9.70 & 1277 & 494 & 1.04 & 71.3 & 210 & 56.2 & 0.015 & 3.71 & 0.017 \\
P95 & 14.4 & 0.39 & 6.37 & 2.00 & 10.5 & 1469 & 579 & 1.08 & 117 & 266 & 81.0 & 0.018 & 5.29 & 0.028 \\
\hline
\end{tabular}


Table 3 Parameters of descriptive statistics, together with geometric mean (GM) and selected percentiles $(\mathrm{Ps})$ in serum samples for trace elements $(\mu \mathrm{g} / \mathrm{L})$ in the hemodialysis patients (HD group)

\begin{tabular}{lcccccccccccccc}
\hline & $\mathrm{Al}$ & $\mathrm{Cr}$ & $\mathrm{Mn}$ & $\mathrm{Co}$ & $\mathrm{Ni}$ & $\mathrm{Cu}$ & $\mathrm{Zn}$ & $\mathrm{As}$ & $\mathrm{Se}$ & $\mathrm{Rb}$ & $\mathrm{Sr}$ & $\mathrm{Cd}$ & $\mathrm{Pb}$ & $\mathrm{U}$ \\
\hline Mean & 30.4 & 0.12 & 4.41 & 0.95 & 10.5 & 1045 & 399 & 0.83 & 81.8 & 106 & 45.0 & 0.015 & 4.13 & 0.0014 \\
SD & 13.5 & 0.06 & 1.97 & 0.38 & 3.43 & 245 & 92.1 & 0.26 & 26.1 & 41.9 & 11.3 & 0.009 & 2.72 & 0.0006 \\
Min & 12.4 & 0.01 & 1.71 & 0.62 & 6.10 & 633 & 262 & 0.43 & 44.7 & 55.7 & 26.7 & 0.006 & 1.25 & 0.0001 \\
Max & 57.8 & 0.27 & 11.1 & 2.67 & 21.0 & 1747 & 682 & 1.65 & 185 & 272 & 91.9 & 0.051 & 14.1 & 0.0035 \\
Median & 26.6 & 0.12 & 4.00 & 0.86 & 9.32 & 1021 & 384 & 0.73 & 80.1 & 92.6 & 42.8 & 0.013 & 3.17 & 0.0012 \\
GM & 27.6 & 0.10 & 4.04 & 0.90 & 9.99 & 1018 & 390 & 0.80 & 78.4 & 99.6 & 43.9 & 0.013 & 3.51 & 0.0012 \\
P5 & 15.4 & 0.03 & 2.17 & 0.66 & 6.60 & 702 & 286 & 0.48 & 53.8 & 67.3 & 32.8 & 0.007 & 1.55 & 0.0006 \\
P25 & 19.3 & 0.07 & 2.81 & 0.72 & 7.78 & 927 & 336 & 0.65 & 62.9 & 81.3 & 39.2 & 0.009 & 2.72 & 0.0011 \\
P50 & 26.6 & 0.12 & 4.00 & 0.86 & 9.32 & 1021 & 384 & 0.73 & 80.1 & 92.6 & 42.8 & 0.013 & 3.17 & 0.0012 \\
P75 & 44.2 & 0.15 & 5.28 & 1.01 & 13.1 & 1154 & 440 & 1.05 & 94.2 & 117 & 48.2 & 0.021 & 4.72 & 0.0017 \\
P95 & 53.6 & 0.23 & 7.64 & 1.46 & 15.4 & 1484 & 571 & 1.17 & 114 & 186 & 62.3 & 0.028 & 9.90 & 0.0021 \\
\hline
\end{tabular}

selenium (Se), strontium (Sr), aluminum (Al), nickel (Ni), manganese $(\mathrm{Mn})$, chromium $(\mathrm{Cr})$, lead $(\mathrm{Pb})$, arsenic (As), cobalt (Co), cadmium (Cd), and uranium (U) (Fig. 1a and b). According to the Kruskal-Wallis test, the HD group differed from $\mathrm{CG}$ for each analyzed trace element (Table S1, Suppl. material). The levels of $\mathrm{Al}, \mathrm{Mn}, \mathrm{Co}, \mathrm{Ni}, \mathrm{Cu}, \mathrm{As}, \mathrm{Se}$, $\mathrm{Sr}$, and $\mathrm{Pb}$ were higher, while the levels of $\mathrm{Cr}, \mathrm{Zn}, \mathrm{Rb}, \mathrm{Cd}$, and $\mathrm{U}$ were lower in HD compared to CG. Higher levels of $\mathrm{Al}$ and $\mathrm{Se}$, as well as lower levels of $\mathrm{As}, \mathrm{Sr}, \mathrm{Zn}, \mathrm{Rb}$, and $\mathrm{U}$, were significant to distinguished HD from PD. Among other analyzed trace elements, $\mathrm{Co}, \mathrm{Se}$, and $\mathrm{U}$ are the only elements that did not distinguish PD from CG $(P>0.05)$ (Tables 1 , 2 , and 3 ). We also analyzed the impact of dialysis vintage (below and above 6 years) on the concentration of trace elements and did not find significant differences for all studied trace elements (Table S2, Suppl. material).

PCA was carried out to obtain a more detailed insight into the data structure and to identify influential variables responsible for certain patterns of the grouping of CG, PD, and HD samples. The PCA model obtained had a pattern with four main components that explain $68.43 \%$ of the total data variance. This model is graphically presented as mutual projections of factor scores and their loads for the first and third main principal components (PCs) (Fig. 2). The score graph revealed the samples grouped into three distinctive clusters according to the levels of the trace elements (Fig. 2a). The first cluster, consisting of CG samples, was distinguished from the other two groups on the left side of the plot, along the PC1 axis, while the separation of the second and third clusters formed from the PD and HD samples, respectively, was evident along the PC3 axis. The loading plot (Fig. 2b), a plot of the direction vectors that define the model, revealed that $\mathrm{Zn}, \mathrm{Cr}, \mathrm{Cd}, \mathrm{Rb}$, and $\mathrm{U}$ had the greatest negative impact on PC1. The high level of these trace elements in the samples of the CG mainly affected their separation from the other groups of samples. The variables that potentially had the greatest influence on the discrimination along PC3 were Se and Al, indicating higher levels of these metals in the
HD patients, while the PD cluster showed higher levels of $\mathrm{Sr}, \mathrm{As}, \mathrm{U}$, and $\mathrm{Rb}$.

\section{Discussion}

Patients on maintenance HD are predisposed to increased risk of trace element imbalance because they have lost the major route of metal excretion and are in close and prolonged contact with an important source of potential systemic exposure, such as dialysis fluid [5]. However, environmental factors that affect each population should also be considered, due to the well-known differences in trace element levels between countries [9].

This study aimed to investigate a wide panel of trace elements and determine whether there is justification for measuring the concentrations of trace elements in PD and HD patients. Given the growing interest in trace elements in $\mathrm{CKD}$, especially in patients on $\mathrm{HD}$, we aimed to determine the serum levels of essential ( $\mathrm{Cr}, \mathrm{Co}, \mathrm{Mn}, \mathrm{Cu}, \mathrm{Zn}$, and $\mathrm{Se}$ ) and toxic trace elements ( $\mathrm{Al}, \mathrm{Ni}, \mathrm{As}, \mathrm{Rb}, \mathrm{Sr}, \mathrm{Cd}, \mathrm{Pb}$, and $\mathrm{U}$ ).

\section{Zinc Levels in Hemodialysis Patients}

Zinc is the most analyzed trace element in serum samples of HD patients. Practically, all investigations confirm reduced serum $\mathrm{Zn}$ levels in HD patients [3, 10]. Our results agree with the previous studies. Some of them also confirmed that serum $\mathrm{Zn}$ levels significantly decreased after HD [2, 10]. Our results reinforce this finding based on the observed lower serum $\mathrm{Zn}$ in HD group compared to the PD group. A recent study by Damianaki et al. [11] showed not only lower circulating Zn levels in CKD patients, but also higher levels of $\mathrm{Zn}$ in daily urine compared to non-CKD participants. Ching-Tang et al. [12] noted serum Zn levels had a statistically decreasing trend in patients in the advanced stages of CKD from stages 1 to 4 . These results also agree with the 
Fig. 1 a Graphical view of mean and standard deviation $(S D)$ values, together with the differences obtained by the Kruskal-Wallis test for concentrations of $\mathrm{Al}, \mathrm{Cr}, \mathrm{Mn}, \mathrm{Co}, \mathrm{Ni}$, $\mathrm{Cu}$, and $\mathrm{Zn}(\mu \mathrm{g} / \mathrm{L})$ between the control group (CG) $(n=50)$, pre-dialysis patients with stage 3 CKD (PD group) $(n=34)$, and hemodialysis patients (HD group) $(n=37)$. Significance: $* P<0.05 ; * * P<0.01$. b Graphical view of mean and standard deviation $(S D)$ values, together with the differences obtained by the Kruskal-Wallis test for concentrations of $\mathrm{As}, \mathrm{Se}, \mathrm{Rb}, \mathrm{Sr}$, $\mathrm{Cd}, \mathrm{Pb}$, and $\mathrm{U}(\mu \mathrm{g} / \mathrm{L})$ between the control group (CG) $(n=50)$, pre-dialysis patients with stage 3 CKD (PD group) ( $n=34$ ), and hemodialysis patients (HD group) $(n=37)$. Significance: $* P<0.05 ; * * P<0.01$

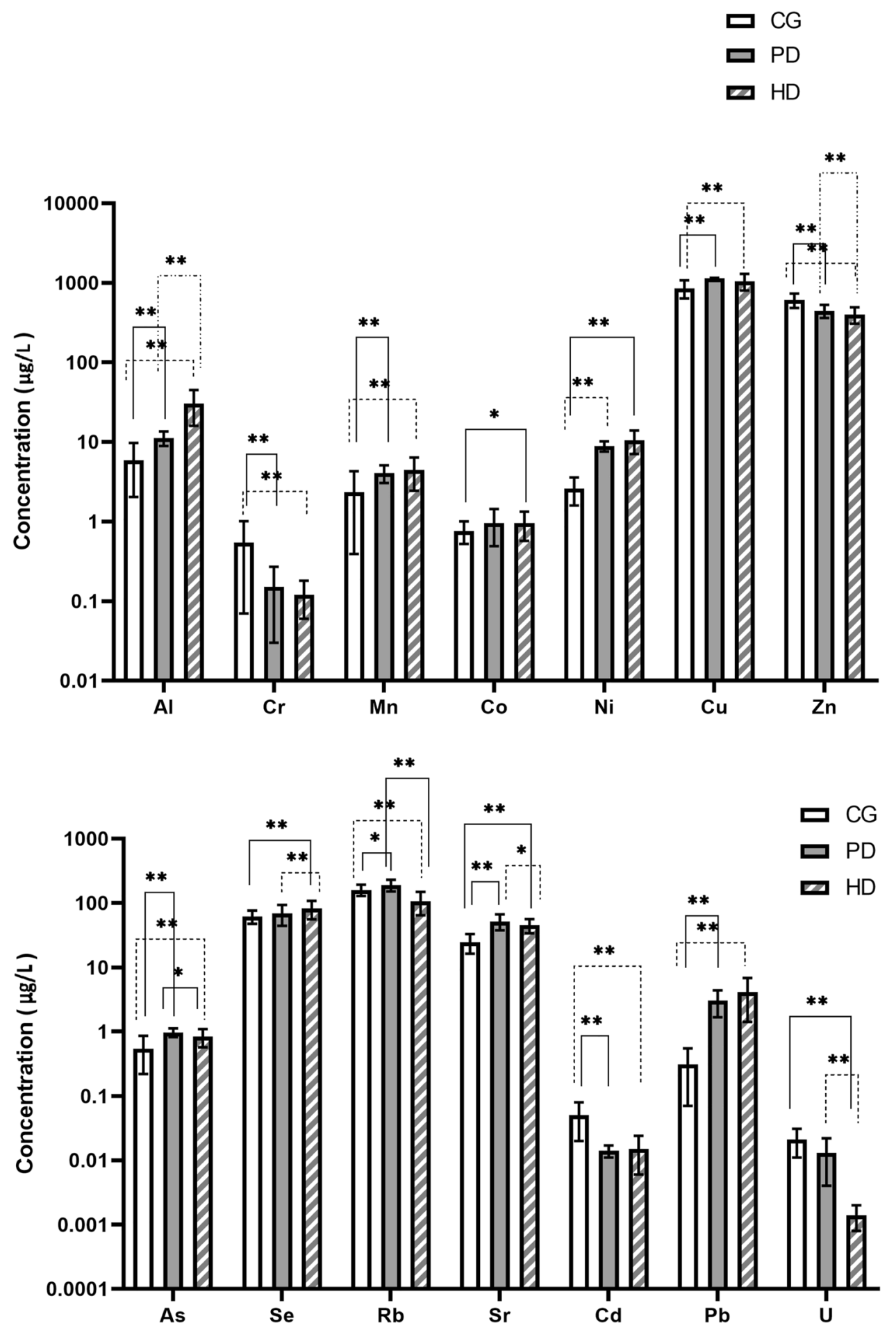

differences we measured in serum $\mathrm{Zn}$ levels in PD and HD groups.

$\mathrm{Zn}$ deficiency can have serious health consequences, such as erythropoietin-resistant anemia, increased susceptibility to kidney damage in diabetes mellitus, immunoglobulin A nephropathy, and risk of atherosclerosis (that has a role in CKD progression and complications) [11]. As an antioxidant and anti-inflammatory mediator, $\mathrm{Zn}$ regulates the function of $\mathrm{T}$ - and B-lymphocytes, making the body's immune system less susceptible to various infections [13]. Recently, the protective role of $\mathrm{Zn}$ in HD patients with COVID-19 has been mentioned [14]. Since it has been noted that $\mathrm{Zn}$ deficiency could increase oxidative stress and atherosclerotic complications, particularly in patients in late-stage renal failure, a 


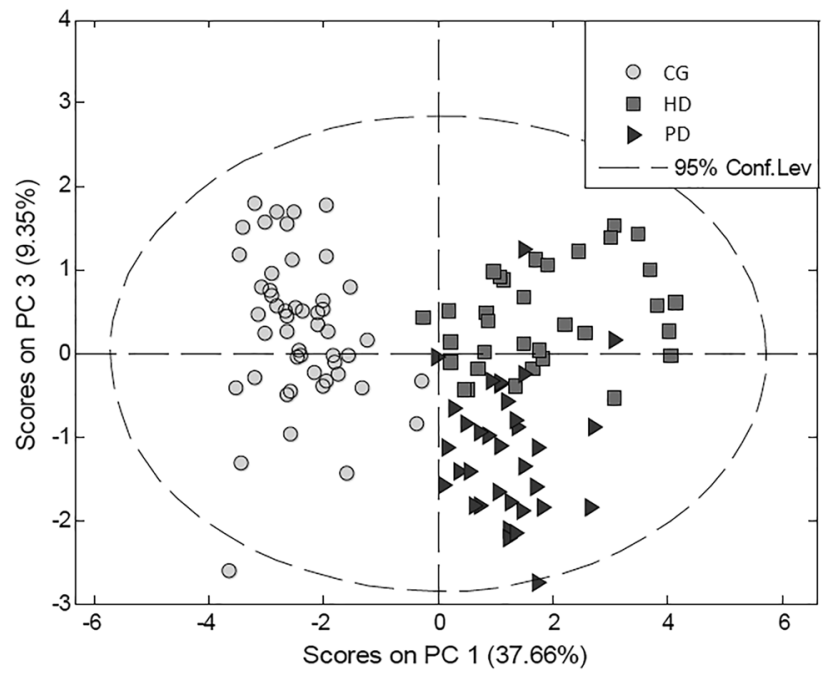

a

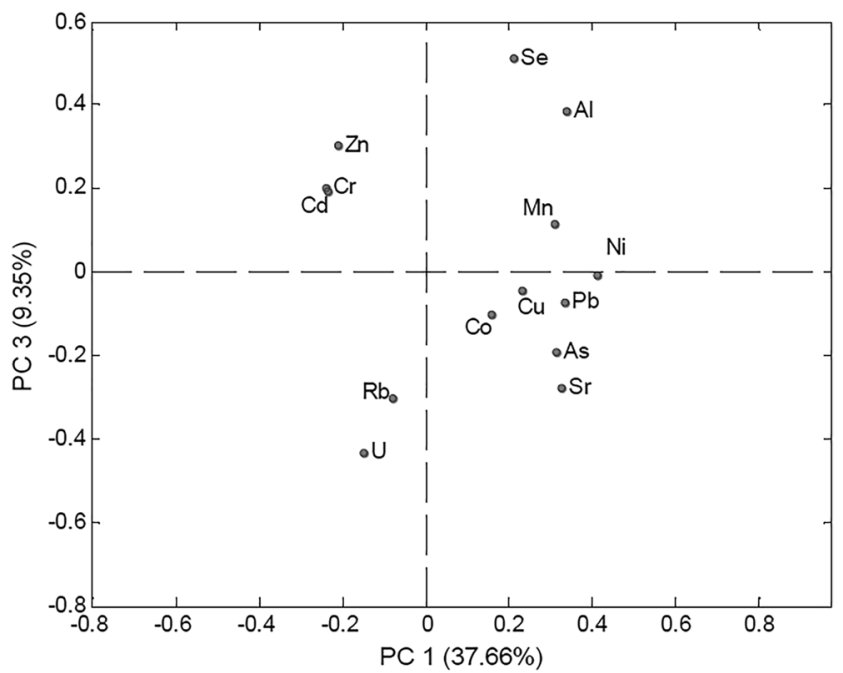

b

Fig. 2 Classification and differentiation of $\mathrm{CD}(n=50), \mathrm{PD}(n=34)$, and $\mathrm{HD}(n=37)$ according to concentrations of analyzed trace elements by principal component analysis (PCA): a score plot; $\mathbf{b}$ loading plot

practical response would be to start timely $\mathrm{Zn}$ supplementation at the moment when patients require initial HD treatment. Dvornik et al. [15] noted that $64 \%$ of HD patients with ESRD had low serum Zn levels and that Zn supplementation could only be recommended in patients with a proven deficiency. Fukushima et al. [16] showed that an anti-ulcer agent containing $34 \mathrm{mg} \mathrm{Zn}$ could be used for zinc deficiency $(<800 \mu \mathrm{g} / \mathrm{L})$. Guo and Wang $[13,17]$ found that patients, before receiving $\mathrm{Zn}$ supplements, had decreased $\mathrm{Zn}$ plasma levels and increased $\mathrm{Cu}$ levels. After treatment with $78 \mathrm{mg}$ of zinc gluconate (11 mg of elemental $\mathrm{Zn}$ per day) during 2 months, the reverse finding was obtained. According to our Serbian database on food composition, the average dietary intake of $\mathrm{Zn}$ was below $8.8 \mathrm{mg} /$ day for $33.3 \%$ of patients with HD; the optimal daily requirement for $\mathrm{Zn}$ is $15 \mathrm{mg}$. This finding could also explain hypozincemia in our HD patients.

Several factors can lead to Zn deficiency in HD patients, including reduced food intake, the HD procedure per se, increased expression of some transporters during inflammation, the deficit of Fe (antagonistic effects), impaired gastrointestinal absorption of $\mathrm{Zn}$ in uremic patients, a deficit of calcitriol, antagonistic effects of $\mathrm{Cu}$ on their common carrier, metallothionein, due to its higher affinity for $\mathrm{Cu}$ than for $\mathrm{Zn}$, etc. [4, 7]. Although many studies have reported that serum levels below $800 \mu \mathrm{g} / \mathrm{L}$ should be considered deficient, clinical symptoms of deficiency have been observed primarily in individuals with serum $\mathrm{Zn}$ levels below $400 \mu \mathrm{g} / \mathrm{L}$ [7]. Thus, the serum $\mathrm{Zn}$ levels obtained in HD patients in this study $(399 \pm 92.1 \mu \mathrm{g} / \mathrm{L})$ could be considered as indicative for $\mathrm{Zn}$ supplementation. The type of HD procedure, its frequency, and the presence of other comorbidities should be evaluated in future studies, which would determine their effects on $\mathrm{Zn}$ turnover. Furthermore, the serum $\mathrm{Zn}$ in PD $(445 \pm 82 \mu \mathrm{g} / \mathrm{L})$ and CG $(607 \pm 125 \mu \mathrm{g} / \mathrm{L})$ also deserve attention, because both levels were below the proposed reference range of $800-1200 \mu \mathrm{g} / \mathrm{L}$ [7]. However, this reference range should be taken with some reserve due to the previously mentioned deficit of this element in soil and food in our country [18]. Therefore, the determined reference interval for serum $\mathrm{Zn}$ in the adult Serbian population, which is from 400 to $825 \mu \mathrm{g} / \mathrm{L}$, strongly implies that our healthy adult populace could be at risk of $\mathrm{Zn}$ deficiency [19].

\section{Other Analyzed Trace Elements}

Studies for other analyzed trace elements in HD patients are contradictory. Most studies agreed that $\mathrm{Cu}$ levels were higher in HD patients than in healthy individuals [20, 21], although there are other studies that showed insignificant [12] or even statistically lower serum $\mathrm{Cu}$ in HD patients than in healthy controls [5]. Tonelli et al. [22] reported an independent association between elevated $\mathrm{Cu}$ levels and risk of death in HD patients. The significantly high serum $\mathrm{Cu}$ levels in patients with HD in this study could be explained by their $\mathrm{Zn}$ deficiency, as it is well known that these two trace elements are antagonists. We also found the $\mathrm{Cu} / \mathrm{Zn}$ ratio could be considered as a marker for HD patients, since a statistical difference was found between the CG $(1.41 \pm 0.88 \mu \mathrm{g} / \mathrm{L})$ and both PD (2.66 \pm 0.57$)$ and HD (2.67 \pm 0.62$)$. Interestingly, the serum $\mathrm{Cu} / \mathrm{Zn}$ ratio of the PD group did not separate these patients from the HD group, indicating the selectivity of this ratio in regard to disease prognosis. 
Tonelli et al. [3] reported that there are associations in blood profiles between HD patients and healthy controls. They found that $\mathrm{Cd}, \mathrm{Cr}$, and $\mathrm{Pb}$ were higher and that $\mathrm{Mn}$ and Se concentrations were lower in patients with HD compared with controls. Agreement with our study was found only for $\mathrm{Pb}$. This discrepancy in the results can be explained by the fact that the study by Tonelli et al. [3] included serum, plasma, and whole blood samples. It is well known that essential trace elements, such as $\mathrm{Mn}, \mathrm{Se}$, and $\mathrm{Cr}$, are naturally higher in whole blood than in serum or plasma samples [23]. These facts could also explain the opposite results for $\mathrm{Mn}, \mathrm{Se}$, and $\mathrm{Cr}$ found by Tonelli et al. [3] compared to our results. Another potential factor that could contribute to these differences is environmental exposure to the mentioned trace elements, which is geographically specific. Thus, the serum Se measured in this study should be carefully interpreted due to the significant lack of this element in the soil and food in our country. The reference interval (P5-P95) for serum Se in the adult Serbian population was $45-98 \mu \mathrm{g} / \mathrm{L}$ [19], which is about half the reference level in other countries [24, 25]. However, our results for HD agree with Gómez de Oña et al. [20]. Greater Se levels in HD than in PD patients suggest the phenomenon of prolonged Se accumulation in their circulatory systems and could be a direct result of their extent of renal failure.

Although the results for Mn are contradictory between published studies, perhaps primarily due to the use of different types of samples, we found agreement with the results of Almeida et al. [5] for this essential trace element. A possible explanation for the elevated $\mathrm{Mn}$ in our HD patients could be the inability to effectively remove it during the dialysis water purification process and/or the fact that the main route of elimination of $\mathrm{Mn}$ from the body is feces rather than urine $[26,27]$. The current study also found that Co levels were higher in HD than in CG. Considering serum Co levels were slightly higher than the accepted reference limit $(<0.90 \mu \mathrm{g} / \mathrm{L})$ reported by Almeida et al. [5], the elevated levels of this element we measured in HD patients $(0.95 \pm 0.38 \mu \mathrm{g} / \mathrm{L})$ could be associated with increased gastrointestinal absorption or exposure through dialysis fluid, due to contact with Co-containing metal alloys.

To the best of our knowledge, there are only a few papers on the status of toxic trace elements in HD patients. The most well-known example of intoxication of HD patients is related to Al. Our results confirm previous findings. It should be noted that hemodialysis is not highly effective in eliminating $\mathrm{Al}$ due to its ability to bind to transferrin (about 90\%) [28]. The findings of our study strongly indicate the justification for considering even stricter quality control of dialysis water, given that the serum Al levels $(30.4 \pm 13.5 \mu \mathrm{g} / \mathrm{L})$ were above $20 \mu \mathrm{g} / \mathrm{L}$, which is characteristic of the symptoms of osteomalacia and/or encephalopathy. Recently, Almeida et al. [5] also reported reduced $\mathrm{Rb}$ and increased $\mathrm{Sr}$ levels in $\mathrm{HD}$ patients. These results agreed well with ours. Canavese et al. [29] not only reported similar results, but also pointed out that $\mathrm{Rb}$ could play a role in neurobehavioral functions, based on the results obtained for the analyzed neural tissues. D'Haese et al. [30] found that HD patients with bone fractures had elevated serum $\mathrm{Sr}$ levels compared to other osteodystrophies. Twofold higher serum $\mathrm{Sr}$ levels in HD $(45 \pm 11.3)$ than in $\mathrm{CG}(24.6 \pm 8.33 \mu \mathrm{g} / \mathrm{L})$ could be explained by the release of $\mathrm{Sr}$ from damaged bones into the vascular system. Gómez de Oña et al. [20] found elevated levels of $\mathrm{Ni}, \mathrm{As}$, and $\mathrm{Pb}$ in $\mathrm{HD}$ patients, which agree with our results. Hypernickelemia has been reported in HD patients. Ramprasad et al. [31] also found increased levels of Ni in HD patients. Our results confirm these previous findings, since the serum Ni levels of $8.86 \pm 1.30$ and $10.5 \pm 3.43 \mu \mathrm{g} / \mathrm{L}$ for PD and HD, respectively, were above the toxicologically relevant limit in HD patients, $10 \mu \mathrm{g} / \mathrm{L}$, as reported by Almeida et al. [5]. Moreover, our results showed that even our CG $(2.59 \pm 1.00 \mu \mathrm{g} / \mathrm{L})$ has serum $\mathrm{Ni}$ levels above the reference limit $(<2 \mu \mathrm{g} / \mathrm{L})$. Although As levels are increased in HD patients, Zhang et al. [32] reported that foods can affect As levels in HD patients, due to the presence of arsenobetaine (AsB), the most common form of As present in the bloodstream. This indicates that As most likely does not pose a significant danger to HD patients, because AsB is non-toxic. In contrast, the high levels of $\mathrm{Pb}$ we measured in the blood of HD patients should be further investigated, as it is well known that $\mathrm{Pb}$ is distributed to the kidneys after gastrointestinal absorption. Atieh Makhlough et al. [33] noted that elevated $\mathrm{Pb}$ levels in HD patients could be due to almost complete loss of renal function and difficulty in removing $\mathrm{Pb}$ during hemodialysis. The status of serum $U$ in patients on HD is unknown. A positive finding of our study is that $\mathrm{U}$ levels were 10 times lower in HD than in PD patients and the CG. This discovery could indicate the importance of $\mathrm{HD}$ as a part of therapeutic protocols which are applied if intoxication with this heavy metal occurs.

It would be instructive to quantify the essential and toxic metals in the circulatory system of HD patients, in order to determine these metals' physiological levels and to prevent any toxicity that could occur at higher levels. We stress that HD patients carry a substantial burden of comorbidities and susceptibility to the more severe symptoms caused by trace elements deficiency and/or toxicity, so any measures contributing to damage mitigation would be welcome.

The limitations of this study are primarily related to the insufficient number of subjects to conduct a deeper statistical analysis in relation to sex, age, and other internal/external factors. However, strict selection of patients without the mentioned chronic diseases limited the number of subjects adequately covered by this study. 


\section{Conclusion}

This study showed significant alterations of circulating trace elements in the bloodstream of HD patients, an important issue that requires attention due to the potential deleterious effects of these metals. The levels of $\mathrm{Al}, \mathrm{Mn}$, $\mathrm{Co}, \mathrm{Ni}, \mathrm{Cu}, \mathrm{As}, \mathrm{Se}, \mathrm{Sr}$, and $\mathrm{Pb}$ were higher, while the levels of $\mathrm{Cr}, \mathrm{Zn}, \mathrm{Rb}, \mathrm{Cd}$, and $\mathrm{U}$ were lower in $\mathrm{HD}$ patients than in our CG. Higher levels of $\mathrm{Al}$ and $\mathrm{Se}$, as well as lower levels of $\mathrm{As}, \mathrm{Sr}, \mathrm{Zn}, \mathrm{Rb}$, and $\mathrm{U}$ were significant to distinguish HD from PD. Among other analyzed elements, $\mathrm{Co}, \mathrm{Se}$, and $\mathrm{U}$ are the only trace elements that did not distinguish PD from CG at a statistically significant level. The HD group had lower serum U levels than the PD group, and this could be a result of hemodialysis. This study also revealed the $\mathrm{Cu} / \mathrm{Zn}$ ratio could be used as a marker for early and late detection of renal failure. Marked changes in serum levels of essential/toxic trace elements indicate additional pathophysiological events in CKD, which could additionally contribute to the preexisting increased morbidity of HD patients. Measurement of trace elements in HD patients should be performed routinely.

Supplementary Information The online version contains supplementary material available at https://doi.org/10.1007/s12011-021-02940-7.

Author Contribution A.S. designed the investigation, conducted the experimental study, analyzed the data, and wrote the first and last version of the paper; S.R. and B.T. collected clinical specimens; D.R.M, S.R., B.R., Đ.K., and D.M. participated in writing through reviewing and editing. All authors contributed critically to the draft and gave final approval for publication. We thank Dr. Marija Takić for her assistance.

Funding This research was financially supported by the Ministry of Education, Science and Technological Development of the Republic of Serbia Contract Number: 451-03-9/2021-14/200288 and by the Ministry of Defence of the Republic of Serbia, Project MFVMA/8/15-17.

Data Availability Data and material are available from the corresponding author on a reasonable request.

Code Availability Not applicable.

\section{Declarations}

Ethics Approval The approval for the study was granted by the Ethical Review Board of the Military Medical Academy, Belgrade, Serbia, in accordance with the principles of the Declaration of Helsinki.

Consent to Participate All patients and healthy blood donors voluntarily participated in this study, and written informed consent from all study participants was obtained according to the ethical standards defined by the Declaration of Helsinki.

Consent for Publication Not applicable.

Competing Interests The authors declare no competing interests.

\section{References}

1. Esmaeili M, Rakhshanizadeh F (2019) Serum trace elements in children with end-stage renal disease. J Ren Nutr 29:48-54. https://doi.org/10.1053/j.jrn.2018.05.005

2. Ahmadipour F, Mahjoub S, Pouramir M, Siahposht A, AfsharNaderi A, Absalan A (2017) Determining serum zinc and magnesium levels in hemodialysis patients could be helpful for clinicians. Ind J Clin Biochem 32:464-467. https://doi.org/10. 1007/s12291-016-0604-7

3. Tonelli M, Wiebe N, Hemmelgarn B, Klarenbach S, Field C, Manns B, Thadhani R, Gill J (2009) Alberta Kidney Disease Network, Trace elements in hemodialysis patients: a systematic review and meta-analysis. BMC Med 7:1-12. https://doi.org/10. 1186/1741-7015-7-25

4. Trendafilov I, Georgieva I, Manolov V, Atanasova B, Vasilev V, Arabadjieva D, Velkova N, Dimitrova V, Yonova D (2018) Status and relation to inflammation of some serum trace elements (TE) in hemodialysis (HD) patients. Nephrol Renal Dis 3:1-4. https://doi.org/10.15761/nrd.1000148

5. Almeida A, Gajewska K, Duro M, Costa F, Pinto E (2020) Trace element imbalances in patients undergoing chronic hemodialysis therapy - report of an observational study in a cohort of Portuguese patients. J Trace Elem Med Biol 62:126580. https:// doi.org/10.1016/j.jtemb.2020.126580

6. Filler G, Felder S (2014) Trace elements in dialysis. Pediatr Nephrol 29:1329-1335. https://doi.org/10.1007/ s00467-013-2585-6

7. Clinical practice guideline for the evaluation and management of chronic kidney disease (2012). Available at: https://kdigo. org/wp-content/uploads/2017/02/KDIGO_2012_CKD_GL.pdf

8. Stojsavljević A, Vujotić Lj, Rovčanin B, Borković-Mitić S, Gavrović-Jankulović M, Manojlović D (2020) Assessment of trace metal alterations in the blood, cerebrospinal fluid and tissue samples of patients with malignant brain tumors. Sci Rep 10:3816. https://doi.org/10.1038/s41598-020-60774-0

9. Zakir HM, Quadir QF, Mollah MZI (2021) Human health risk assessment of heavy metals through the consumption of common foodstuffs collected from two divisional cities of Bangladesh. Expo Health 13:253-268. https://doi.org/10.1007/ s12403-020-00380-7

10. Anees M, Mumtaz A, Frooqi S, Ibrahim M, Hameed F (2011) Serum trace elements (aluminium, copper, zinc) in hemodialysis patients. Biomedica 27:106-110

11. Damianaki K, Lourenco JM, Braconnier P, Ghobril JP, Devuyst O, Burnier M, Lenglet S, Augsburger M, Thomas A, Pruijm M (2020) Renal handling of zinc in chronic kidney disease patients and the role of circulating zinc levels in renal function decline. Nephrol Dial Transplant 35:1163-1170. https://doi.org/10.1093/ ndt/gfz065

12. Ching-Tang S, Ying-Ling S, Chiou-An C, Hsin-Yu L, YeouLih H, Ching-Chiang L (2012) Changes in levels of copper, iron, zinc, and selenium in patients at different stages of chronic kidney disease. Genom Med Biomark Health Sci 4:128-130. https://doi.org/10.1016/j.gmbhs.2013.03.001

13. Guo CH, Chen PC, Hsu GS, Wang CL (2013) Zinc supplementation alters plasma aluminum and selenium status of patients undergoing dialysis: a pilot study. Nutrients 5:1456-1470. https://doi.org/10.3390/nu5041456

14. Toida T, Toida R, Ebihara S, Takahashi R, Komatsu H, Uezono S, Sato Y, Fujimoto S (2020) Association between serum zinc levels and clinical index or the body composition in incident hemodialysis patients. Nutrients 12:3187. https://doi.org/10. $3390 /$ nu 12103187 
15. Dvornik Š, Ćuk M, Rački S, Zaputović L (2006) Serum zinc concentrations in the maintenance hemodialysis patients. Coll Antropol 30:125-129

16. Fukushima T, Horike H, Fujiki S, Kitada S, Sasaki T, Kashihara N (2009) Zinc deficiency anemia and effects of zinc therapy in maintenance hemodialysis patients. Ther Apher Dial 13:213-219. https://doi.org/10.1111/j.1744-9987.2009.00656.x

17. Guo CH, Wang CL (2013) Effects of zinc supplementation on plasma copper/zinc ratios, oxidative stress, and immunological status in hemodialysis patients. Int J Med Sci 10:79-89. https:// doi.org/10.7150/ijms.5291

18. Nikolic M, Nikolic N, Kostic L, Pavlovic J, Bosnic P, Stevic N, Savic J, Hristov N (2016) The assessment of soil availability and wheat grain status of zinc and iron in Serbia: implications for human nutrition. Sci Total Environ 553:141-148. https://doi.org/ 10.1016/j.scitotenv.2016.02.102

19. Stojsavljević A, Jagodić J, Vujotić L, Borković-Mitić S, RašićMilutinović Z, Jovanović D, Gavrović-Jankulović M, Manojlović D (2020) Reference values for trace essential elements in the whole blood and serum samples of the adult Serbian population: significance of selenium deficiency. Environ Sci Pollut Res Int 27:1397-1405. https://doi.org/10.1007/s11356-019-06936-8

20. Gómez de Oña C, Martínez-Morillo E, Gago González E, Vidau Argüelles P, FernándezMerayo C, Álvarez Menéndez FV (2016) Variation of trace element concentrations in patients undergoing hemodialysis in the north of Spain. Scand J Clin Lab Invest 76:492-499. https://doi.org/10.1080/00365513.2016.1201852

21. Ari E, Kaya Y, Demir H, Asicioglu E, Keskin S (2011) The correlation of serum trace elements and heavy metals with carotid artery atherosclerosis in maintenance hemodialysis patients. Biol Trace Elem Res 144:351-359. https://doi.org/10.1007/ s12011-011-9103-0

22. Tonelli M, Wiebe N, Bello A, Field CJ, Gill JS, Hemmelgarn BR, Holmes DT, Jindal K, Klarenbach SW, Manns BJ, Thadhani R, Kinniburgh D (2018) Alberta Kidney Disease Network, Concentrations of trace elements and clinical outcomes in hemodialysis patients: a prospective cohort study. Clin J Am Soc Nephrol 13:907-915. https://doi.org/10.2215/cjn.11451017

23. Xu B, Zhang Y, Chen Y, Zeng M, Feng J, Tang J, Yu L (2020) Simultaneous multielement analysis by ICP-MS with simple whole blood sample dilution and its application to uremic patients undergoing long-term hemodialysis. Scand J Clin Lab Invest 80:247-255. https://doi.org/10.1080/00365513.2020.1729401

24. Kim HJ, Lim HS, Lee KR, Choi MH, Kang NM, Lee CH, Oh EJ, Park HK (2017) Determination of trace metal levels in the general population of Korea. Int J Environ Res Public Health 14:1-12. https://doi.org/10.3390/ijerph14070702

25. Schultze B, Lind PM, Larsson A, Lind L (2013) Whole blood and serum concentrations of metals in a Swedish population-based sample. Scand J Clin Lab Invest 1:1-6. https://doi.org/10.3109/ 00365513.2013.864785

26. Prodanchuk M, Makarov O, Pisarev E, Sheiman B, Kulyzkiy M (2014) Disturbances of trace element metabolism in ESRD patients receiving hemodialysis and hemodiafiltration. Cent Eur J Urol 66:472-476. https://doi.org/10.5173/ceju.2013.04.art23

27. Kaya Y, Ari E, Demir H, Gecit I, Beytur A, Kaspar C (2012) Serum cadmium levels are independently associated with endothelial function in hemodialysis patients. Int Urol Nephrol 44:14871492. https://doi.org/10.1007/s11255-011-0055-2

28. EFSA (European Food Safety Authority) (2008) Safety of aluminium from dietary intake. Scientific opinion of the panel on food additives, flavourings, processing aids and food contact materials (AFC). EFSA J 754:1-34

29. Canavese C, DeCostanzi E, Branciforte L, Caropreso A, Nonnato A, Pietra R, Fortaner S, Jacono F, Angelini G, Gallieni M, Fop F, Sabbioni E (2001) Rubidium deficiency in dialysis patients. J Nephrol 14:169-175

30. D'Haese PC, Schrooten I, Goodman WG, Cabrera WE, Lamberts LV, Elseviers MM, Couttenye MM, De Broe ME (2000) Increased bone strontium levels in hemodialysis patients with osteomalacia. Kidney Int 57:1107-1114. https://doi.org/10.1046/j.1523-1755. 2000.00938.x

31. Ramprasad N (2013) I. Al-Ghonaim Mohammed, Role of trace elements and lipid peroxidation levels in pre and post hemodialysis of chronic renal failure patients. Int J Res Biochem Biophys $3: 1-6$

32. Zhang X, Cornelis R, De Kimpe J, Mees L, Vanderbiesen V, De Cubber A, Vanholder R (1996) Accumulation of arsenic species in serum of patients with chronic renal disease. Clin Chem 42:1231-1237. https://doi.org/10.1093/clinchem/42.8.1231

33. Makhlough A, Shokrzadeh M, Maryam S, Siyavash A (2014) Comparative analysis of serum levels of aluminum and lead in dialysis patients, pre and post dialysis. Res Mol Med 2:45-49. https://doi.org/10.18869/acadpub.rmm.2.2.45

Publisher's Note Springer Nature remains neutral with regard to jurisdictional claims in published maps and institutional affiliations. 